\title{
mec-7 is a $\beta$-tubulin gene required for the production of 15-protofilament microtubules in Caenorhabditis elegans
}

\author{
Cathy Savage, ${ }^{1,5}$ Michel Hamelin, ${ }^{2}$ Joseph G. Culotti, ${ }^{2}$ Alan Coulson, ${ }^{3}$ Donna G. Albertson, ${ }^{3,4}$ and \\ Martin Chalfie ${ }^{1}$ \\ ${ }^{1}$ Department of Biological Sciences, Columbia University, New York, New York, 10027 USA; ${ }^{2}$ Division of Molecular \\ Immunology and Neurobiology, Mt. Sinai Hospital Research Institute, Toronto, Ontario, Canada M5G 1 X5 ${ }^{3}$ Laboratory of \\ Molecular Biology, Medical Research Council Centre, Cambridge CB2 2QH, UK
}

\begin{abstract}
In the nematode Caenorhabditis elegans, microtubules with 15 protofilaments are a specialized feature of six touch-receptor neurons; microtubules found in other $C$. elegans neurons have 11 protofilaments. Mutations in the gene mec-7 result in touch-insensitive animals whose touch cells lack the 15-protofilament microtubules. We have characterized 54 mutations in the mec-7 gene. The absence of mec-7 activity results selectively in the recessive loss of touch sensitivity. Partial loss-of-function alleles result in a partial loss of touch sensitivity. Dominant mutations, which are isolated at an unusually high proportion, may encode abnormal products. We have cloned the mec-7 gene; it encodes a $\beta$-tubulin which is $90-93 \%$ identical to vertebrate $\beta$-tubulin. Our results are consistent with the hypothesis that tubulin heterogeneity contributes to the formation of structurally and functionally distinct sets of microtubules.
\end{abstract}

[Key Words: Caenorhabditis elegans; $\beta$-tubulin; tubulin mutants; microtubule structure; protofilament number] Received February 14, 1989; revised version accepted March 29, 1989.

Although ubiquitous in eukaryotes, microtubules display considerable structural diversity. They can exist as singlets or doublets and in specialized arrays (Tucker 1979; Dustin 1984) and can vary in the number of protofilaments (Tilney et al. 1973; Burton et al. 1975; Nagano and Suzuki 1975; Chalfie and Thomson 1982; Saito and Hama 1982; Eichenlaub-Ritter and Tucker 1984; Tucker et al. 1985; Mogensen and Tucker 1987). How this structural diversity is produced is not known. Fulton and Simpson (1976) and, more recently, Cleveland (1987) have suggested that diversity in tubulin protein structure, encoded genetically, may be partially responsible for the formation of structurally and functionally distinct sets of microtubules. Post-translational modifications of tubulin (L'Hernault and Rosenbaum 1985) and/ or different microtubule-associated proteins may also contribute to the production of specialized microtubules. Experiments by Scheele et al. (1982) and Evans et al. (1985), for example, have suggested that protofilament number is determined, at least in part, by microtubule initiation.

We have studied the specification of microtubule structure and function in Caenorhabditis elegans because this organism possesses an unusual, cell-specific microtubule that can be altered by mutation. Most neu-

4Present address: Molecular Genetics Unit, Medical Research Council Centre, Cambridge CB2 2QH, U.K.

${ }^{5}$ Corrresponding author. rons in C. elegans have microtubules with 11 protofilaments; the six touch-receptor neurons contain $\sim 45015$ protofilament microtubules and, at most, 1 or 211 -protofilament microtubules (Chalfie and Thomson 1982). Mutations in the gene mec-7 result in animals that are insensitive to gentle touch and whose touch cell processes lack the 15-protofilament microtubules. Touch cells in the two mec-7 mutants examined in serial sections (e1506 and $e 1343$ ) contain $\sim 10011$-protofilament microtubules that do not associate into structured bundles as do the 15-protofilament microtubules (Chalfie and Thomson 1982). The 11-protofilament microtubules allow the outgrowth of touch cell processes but are insufficient for sensory transduction. Microtubule structure in other cells does not appear to be affected in mec-7 mutants.

In this paper we describe a genetic and molecular analysis of the mec-7 gene. We have characterized $54 \mathrm{mec}-7$ mutations. Some mutations, including two complete deletions of the gene, result in the recessive loss of touch sensitivity. Other mutations are expressed as hypomorphs or antimorphs yet still appear to affect only touch sensitivity. The sequence of the cloned mec-7 gene reveals that it encodes a $\beta$-tubulin that is similar to vertebrate $\beta$-tubulins. Our data suggest that the formation of structurally and, perhaps, functionally unique microtubules can, at least in part, be mediated by the use of a specialized $\beta$-tubulin. 


\section{Results}

mec-7 mutations produce a range of touch insensitive phenotypes

We have classified the $54 \mathrm{mec}-7$ mutations into five phenotypic groups (Table 1) (1) strong recessive (15 alleles); (2) weak recessive (8 alleles); 3 ) weak semidominant (i.e., both homozygotes and heterozygotes show a weak phenotype; 12 alleles); (4) strong semidominant (i.e., the homozygotes have a strong phenotype, and the heterozygotes, a weak one; 13 alleles); (5) strong dominant $(6$ alleles). Mutants showing a strong phenotype are completely touch insensitive; those showing a weak phenotype are partially touch sensitive and display a position dependence in their response (see below).

\section{Dominant mec-7 mutations are antimorphic}

More than half of the mec-7 alleles produce a dominant or semidominant phenotype. These alleles probably act as antimorphs, generating products that interfere with normal mec-7 function. As described in Methods, we constructed animals containing a chromosomal deficiency of the mec-7 region (Fig. 1) in trans to a copy of the wild-type mec-7 gene $|u D f 1 /+|$ to determine whether a loss of gene activity produces a dominant phenotype. Because these animals are phenotypically wild type, the complete loss of gene activity is expressed recessively. The dominant phenotypes are therefore not the result of haploinsufficiency. We increased mec-7(+) dosage (as described in Methods) to determine whether the dominant phenotypes are due to the overexpression of normal gene product or to the expression of an aberrant product. mec- $7 /+/+$ strains constructed with the translocated duplication $s t D p 2$, which contains a copy of the wild-type mec-7 gene, and the dominant alleles $e 1527, n 434, u 18, u 129$, and $u 162$ showed partial rescue of touch sensitivity by the extra dose of mec-7(+) at $20^{\circ} \mathrm{C}$ (Table 2). In addition, the mec- $7 /+/+$ construct with the semidominant allele e1505 was completely wild type at $25^{\circ} \mathrm{C}$.

Additional support for the hypothesis that these alleles encode aberrant products comes from an examination of temperature effects. Chalfie and Thomson (1982) found that both the expressivity and penetrance of the touch-insensitive phenotype was higher at $25^{\circ} \mathrm{C}$ than at $15^{\circ} \mathrm{C}$ for heterozygotes containing the $e 1343, e 1505$, $e 1522$, and $e 1527$ alleles. We have found this temperature sensitivity to be a general property: Heterozygotes carrying a single copy of any of the dominant or semidominant mec-7 alleles (except $n 434$ ) are more completely touch insensitive at $25^{\circ} \mathrm{C}$ than at $15^{\circ} \mathrm{C}$ (Table 1). In addition, $n 434 /+/+$ animals are more completely touch insensitive at $20^{\circ} \mathrm{C}$ than at $15^{\circ} \mathrm{C}$ (Table 2).

\section{Loss of mec-7 function causes only touch insensitivity}

The recessive expression of complete touch insensitivity (i.e., the strong, recessive phenotype) is likely to be the result of the complete loss of mec-7 function. Two $\gamma$-ray-induced mutations, $u 443$ and $u 448$, which produce this phenotype, are deletions of $\sim 28$ and $18 \mathrm{~kb}$, respectively, which include the mec-7 gene (see below). Furthermore, a screen for noncomplementing mutations (described in Methods) yielded only mec-7 alleles that result in touch insensitivity. Because mec-7 (e1506)/ $u D f 1$ animals are touch insensitive, mutations causing more severe defects, such as uncoordination or lethality, could in theory be isolated in a screen for mutations that fail to complement $e 1506$ for touch sensitivity. None of the eight mutations identified in this way from 9700 ethyl methanesulfonate (EMS)-mutagenized chromosomes caused more severe defects: Six produced a strong recessive phenotype, one a weak recessive phenotype, and one a weak semidominant phenotype. All eight are $\mathrm{X}$ linked and thus likely to be mec-7 defects.

Heterozygotes of two of the weak alleles, u305(r) and $u 156$ (sd), with $u D f 1$ are more strongly touch insensitive than the corresponding homozygotes. Thus, the weak alleles are not due to the complete loss of mec-7 gene activity but are likely to be hypomorphic, partial loss-offunction mutations.

Position dependence of touch sensitivity in weak alleles Chalfie and Sulston (1981) showed that touch in the anterior of the worm is sensed by three anterior touch cells (ALML, ALMR, and AVM; Fig. 2), whereas touch in the posterior of the worm is sensed by two posterior touch cells (PLML and PLMR; Fig. 2). Mutants with different mec-7 mutations differ in their response to touch at various positions along their bodies (Table 1; Fig. 2). Wild-type worms sense touch along their entire lengths, whereas homozygotes for strong mec-7 alleles, for example, e1506, do not respond to touch at any position [except at the very tips of the head and tail, where even animals lacking touch cells respond (Chalfie and Sulston 1981)]. Many mutants, however, display a partial phenotype. These animals respond more readily when touched at the pharynx (position A in Fig. 2) than at a position more posterior to the pharynx (position B). Similarly, many mutants respond more readily when touched at the tail at a position near the anus (position $\mathrm{D}$ ) than at a more anterior location (position C). The spatial differences in touch sensitivity do not correlate with the distance from the touch cell body. Rather, the degree of touch sensitivity correlates with the distance from the touch cell synapses, which are made near position A in the head and near position D in the tail (Chalfie et al. 1985).

mec-7 is a $\beta$-tubulin gene

The mec-7 gene appears to encode a $\beta$-tubulin. A number of $C$. elegans tubulin genes have been cloned and characterized (Gremke 1986). One of these (a $\beta$-tubulin gene originally called $t u b-2)$ is contained in a series of contiguous cosmid clones (Coulson et al. 1986). One of the cosmids in this series mapped by in situ hybridization to the region of the $\mathrm{X}$ chromosome near 
Savage et al.

Table 1. Touch-insensitive phenotype of mec-7 mutants

\begin{tabular}{|c|c|c|c|c|c|c|c|}
\hline \multirow[b]{2}{*}{ Class } & \multirow[b]{2}{*}{ Allele } & \multicolumn{2}{|c|}{$\mathrm{m} / \mathrm{m}\left(25^{\circ} \mathrm{C}\right)^{\mathrm{a}}$} & \multicolumn{2}{|c|}{$\mathrm{m} /+\left(25^{\circ} \mathrm{C}\right)^{\mathrm{a}}$} & \multicolumn{2}{|c|}{$\mathrm{m} /+\left(15^{\circ} \mathrm{C}\right)^{\mathrm{a}}$} \\
\hline & & head & tail & head & tail & head & tail \\
\hline \multirow[t]{15}{*}{ Strong recessive } & $e 1506$ & - & - & + & + & + & + \\
\hline & $u 142$ & - & - & + & + & + & + \\
\hline & $u 176$ & - & - & + & + & + & + \\
\hline & $u 178$ & - & - & + & + & + & + \\
\hline & $u 275$ & - & - & + & + & + & + \\
\hline & u388 & - & - & + & + & + & + \\
\hline & $u 428$ & - & - & + & + & ND & ND \\
\hline & $u 429$ & - & - & + & + & ND & ND \\
\hline & $u 432$ & - & - & + & + & ND & ND \\
\hline & $u 433$ & - & - & + & + & ND & ND \\
\hline & $u 434$ & - & - & + & + & $\mathrm{ND}$ & ND \\
\hline & $u 440$ & - & - & + & + & ND & ND \\
\hline & $u 443$ & - & - & + & + & ND & ND \\
\hline & $u 448$ & - & - & + & + & ND & ND \\
\hline & $u 453$ & - & - & + & + & $\mathrm{ND}$ & ND \\
\hline \multirow[t]{8}{*}{ Weak recessive ${ }^{b}$} & $u 80$ & - & - & + & + & + & + \\
\hline & $u 88$ & - & - & + & + & + & + \\
\hline & $u 170$ & \pm & \pm & + & + & + & + \\
\hline & u173 & + & \pm & + & + & + & + \\
\hline & u305 & \pm & \pm & + & + & + & + \\
\hline & $u 382$ & - & - & + & + & + & + \\
\hline & $u 430$ & \pm & \pm & + & + & ND & ND \\
\hline & $u 431$ & - & - & + & + & ND & ND \\
\hline \multirow[t]{12}{*}{ Weak semi-dominant ${ }^{b}$} & $e 1522$ & - & - & - & \pm & + & + \\
\hline & $u 48$ & - & - & - & \pm & \pm & + \\
\hline & $u 58$ & - & - & \pm & + & + & + \\
\hline & u127 & - & - & \pm & + & + & + \\
\hline & u136 & - & - & \pm & + & + & + \\
\hline & $u 145$ & - & \pm & \pm & + & + & + \\
\hline & $u 156$ & - & \pm & \pm & + & + & + \\
\hline & u225 & - & - & - & + & + & + \\
\hline & u262 & - & \pm & \pm & + & + & + \\
\hline & $u 278$ & - & \pm & \pm & + & + & + \\
\hline & u319 & - & \pm & \pm & + & + & + \\
\hline & $u 427$ & - & \pm & \pm & + & ND & ND \\
\hline \multirow[t]{13}{*}{ Strong semi-dominant } & $e 1343$ & - & - & - & + & + & + \\
\hline & e1505 & - & - & \pm & + & + & + \\
\hline & $u 9$ & - & - & \pm & + & + & + \\
\hline & u10 & - & - & \pm & + & + & + \\
\hline & $u 98$ & - & - & - & + & + & + \\
\hline & $u 143$ & - & - & \pm & + & + & + \\
\hline & u222 & - & - & \pm & + & + & + \\
\hline & u223 & - & - & - & \pm & + & + \\
\hline & u234 & - & - & - & \pm & + & + \\
\hline & u249 & - & - & \pm & \pm & + & + \\
\hline & u445 & - & - & - & \pm & ND & ND \\
\hline & u449 & - & - & \pm & + & ND & ND \\
\hline & $u 451$ & - & - & \pm & + & ND & $\mathrm{ND}$ \\
\hline \multirow[t]{6}{*}{ Dominant } & e1527 & - & - & - & - & \pm & + \\
\hline & $n 434$ & - & - & - & - & - & - \\
\hline & u18 & - & - & - & - & - & \pm \\
\hline & u129 & - & - & - & - & - & + \\
\hline & u162 & - & - & - & - & \pm & + \\
\hline & $u 283$ & - & - & - & - & \pm & + \\
\hline
\end{tabular}

Animals were touched at position B (Fig. 2) in the head and at position D (Fig. 2) in the tail, as described in Chalfie and Sulston (1981). a $(+)$ Touch sensitive; $( \pm)$ partially touch sensitive; $(-)$ touch insensitive; as defined in Methods; (ND) not determined.

$b$ Weak alleles are those that produce partial phenotypes at any of the positions indicated in Fig. 2. 


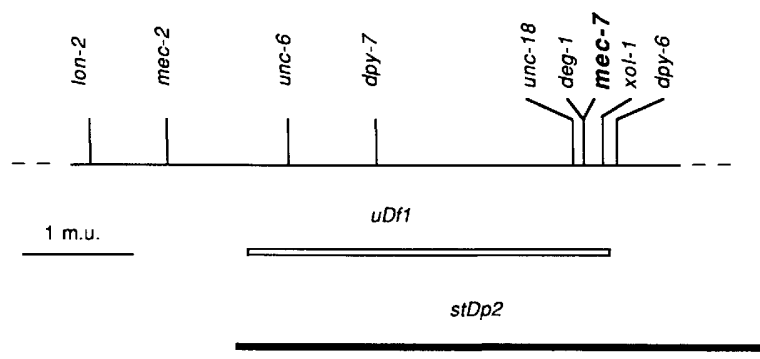

Figure 1. Genetic map surrounding the mec-7(X) locus. The open bar shows the extent of the chromosomal deficiency $u D f 1$; the solid bar shows the extent of the duplication $s t D p 2$. The gene $x o l-1$ has been mapped to the interval between mec-7 and dpy-6 (L. Miller, pers. comm.). All other map positions are from data presented in the text or from Edgley and Riddle (1987). mec-7. Probes containing this $\beta$-tubulin gene identified DNA fragment length differences in several mec-7 mutant strains. One of these differences, a deletion in the e1505 strain (Fig. 3), was used to map the $\beta$-tubulin gene relative to mec-7. None of $9 \mathrm{Unc}$ and 17 of $18 \mathrm{Dpy}$ recombinants from the heterozygote unc-18+dpy-6/ + mec-7(e1505) + showed the Mec phenotype. Genomic DNA from all of the Mec animals, but from none of the nonMec animals, contained the deletion /data not shown). Thus, the deletion and the mec-7 mutation are within 0.02 map units.

We have used the cosmid R02A8 containing the $\beta$-tubulin gene and a subfragment of this cosmid to probe genomic DNA from wild type and from mec-7 mutants. DNAs from seven mec-7 mutants exhibit restriction fragment length differences when probed with R02A8

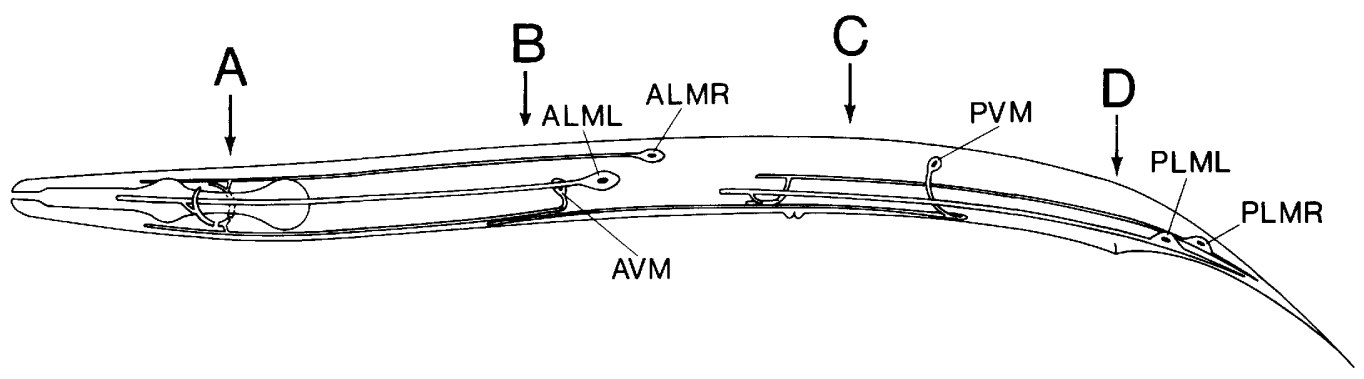

Sensitivity at:

$\begin{array}{lcccc}\text { Allele } & \text { A } & \text { B } & \text { C } & \text { D } \\ \text { wild type } & + & + & + & + \\ e 1506 & - & - & - & - \\ \text { e1522 } & +/- & - & - & - \\ u 48 & +/- & - & - & - \\ u 58 & +/- & - & - & - \\ u 80 & +/- & - & - & - \\ u 88 & +/- & - & - & - \\ u 127 & +/- & - & +/- & +/- \\ u 136 & +/- & - & - & +/- \\ u 145 & +/- & - & +/- & +1- \\ u 156 & +/- & + & - & - \\ u 170 & + & - & - & +/- \\ u 173 & + & - & +/- & +1- \\ u 225 & +/- & - & +/- & +/- \\ u 262 & - & - & - & +/- \\ u 275 & +/- & - & - & +/- \\ u 278 & + & - & - & +/- \\ u 305 & +/- & +/- & - & -\end{array}$

Figure 2. Position dependence of touch sensitivity. $(+)$ Touch sensitive; $( \pm)$ partially touch sensitive; $(-)$ touch insensitive. 
A

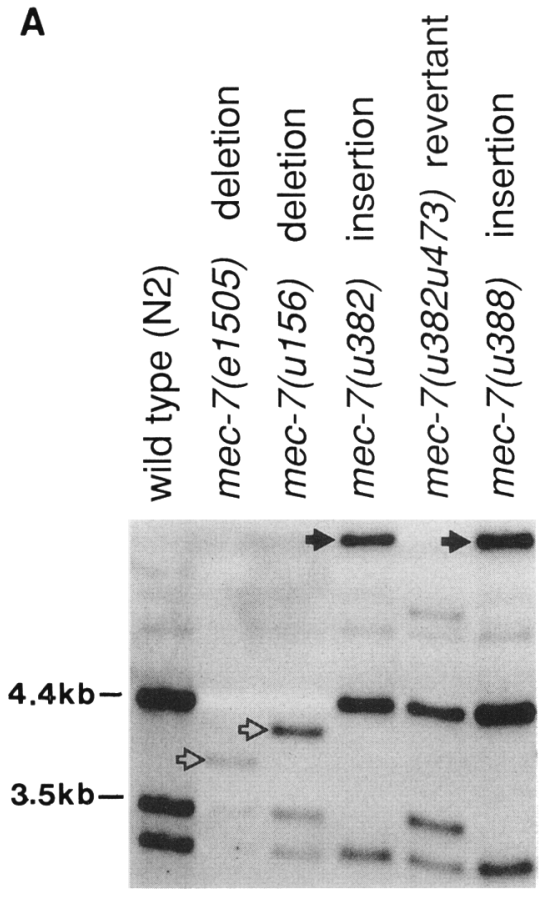

B
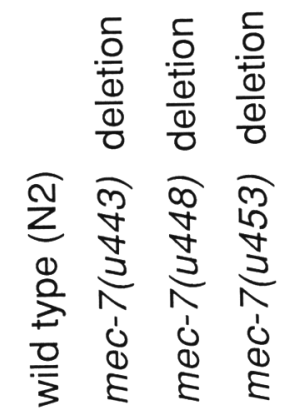

$4.4 \mathrm{~kb}-$

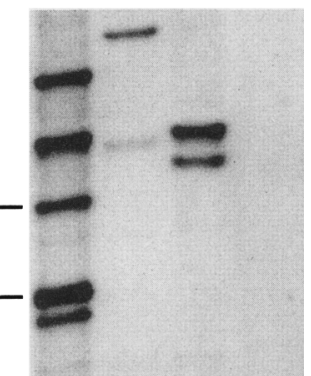

Figure 3. Southern blots of wild-type and mec-7 mutants. (A) Genomic DNAs from wild-type (N2), two EMS-derived mec-7 mutants (e1505 and u156), two TR679-derived mec-7 mutants (u382 and u388), and a wild-type revertant of the TR679 mutant u382 (u382u473) were probed with a 10-kb BgIII fragment isolated from cosmid R02A8 that contains the $\beta$-tubulin sequence. The coding sequence is contained within the 3.5- and 4.4-kb EcoRI fragments. Open arrows identify deletions in the 4.4-kb fragment; solid arrows identify insertions in the $3.5-\mathrm{kb}$ fragment. $(B)$ Genomic DNAs from wild-type and three $\gamma$-ray-induced mutants $(u 443, u 448$, and $u 453)$ were probed with the entire R02A8 cosmid.

(Fig. 3). Five mutants, two from EMS mutagenesis (e1505 and $u 156)$ and three from $\gamma$-ray mutagenesis (u443, u448, and u453) contain deletions. The EMS mutations delete $\sim 600$ and $300 \mathrm{bp}$, respectively, of DNA from the 4.4-kb wild-type EcoRI fragment, which contains most of the tubulin-coding sequence and $\sim 3 \mathrm{~kb}$ of upstream sequences. Two of the $\gamma$-ray mutations (u443 and $u 448$ ) delete $\sim 28$ and $18 \mathrm{~kb}$, respectively, of DNA, which includes the region that hybridizes with a chicken $\beta$-tubulin cDNA probe (Fig. 3B). Animals homozygous for these mutations are completely touch insensitive but show no other behavioral defects. The third $\gamma$-ray-induced mutation $(u 453)$ deletes $>40 \mathrm{~kb}$ of DNA (Fig. 3B) and results in additional defects (partial lethality at $25^{\circ} \mathrm{C}$ and poor male mating). These additional phenotypes are probably associated with defects in one or more adjacent genes. DNAs from two other mutants [u382 and u388, both derived from a mutator strain, TR679 (Collins et al. 1987)] contain insertions of $\sim 3.5 \mathrm{~kb}$ in the 3.5-kb wild-type EcoRI fragment (Fig. 3A). The insertions are not seen in wild-type revertants derived from these animals (Fig. 3A and data not shown). The insertions are located between the EcoRI site at position 1830 in the coding sequence and a BglII site $\sim 600$ bp downstream of the coding sequence. Taken together, these data provide strong evidence that mec-7 is the tub-2 $\beta$-tubulin gene.
Sequence of the mec-7 gene

We have determined the nucleotide sequence of $2100 \mathrm{bp}$ of DNA that appears to include the entire coding region of mec-7 and 338 bp of upstream sequence (Fig. 4). The putative tubulin-coding sequence is interrupted by four small introns. Each putative intron is bounded by consensus $C$. elegans donor and acceptor splice sites (Emmons 1988), and each contains stop codons in all three reading frames. The tubulin predicted from the putative exon sequences has 441 amino acids. No known regulatory sequences were found in the upstream region, nor does it contain consensus splice acceptor or splice donor sites. Therefore, this region is unlikely to be an intron.

The coding sequence is $90-93 \%$ identical to that of vertebrate $\beta$-tubulins and the testis-specific $\beta$-tubulin of Drosophila (Table 3; Fig. 5). Sequence identity is lower in comparison with other $\beta$-tubulins. The carboxyterminal region beyond amino acid 430 is highly divergent in mec-7, as it is in other $\beta$-tubulins and is the shortest of any reported $\beta$-tubulin (Sullivan and Cleveland 1986; Rudolph et al. 1987; Burland et al. 1988). In addition to these differences at the carboxyl terminus, only seven residues in the mec-7 peptide sequence are not shared by other reported $\beta$-tubulins: residues 35 (Gln), 127 (Thr), 198 (Ser), 278 (Asn), 293 (Cys), 343 (Asp), and 429 (Ala) 
Downloaded from genesdev.cshlp.org on April 26, 2023 - Published by Cold Spring Harbor Laboratory Press

Genetic analysis of mec-7 $\beta$-tubulin TATTTTCAGTTATAATGTTCCTAGTTFTGCTTTATGCCAAGCAATTTCAGTTCTGGGAGGTAATATCCGATGAACACGGCATTGACCCATCTGGCCAGTA

MetArgGluIleValHisIleGlnAlaGlyGlnCysGlyAsnGlnIleGlySerLys TGTAGAGGAAGAAACGTCGGGTCCAAATTTCAAGCAACATGCGCGAGATCGTTCATATTCAAGCCGGACAATGCGGTAATCAAATCGGTTCGAAGGTTAG

PheTrpGluValIleSerAspGluH1sGlyIleAspProSerGlyGlnTyr

ValGlyAspSerAspLeuGInLeuGluArg IleAsnValTyrTyrAsnGluAlaGlySerAsnLysTyrValProArg

501 TGTGGGAGACTCTGATCTTCAACTCGAAAGAATCAACGTCTACTATAATGAGGCCGGAAGCAACAAATATGTTCCAAGGT

601

AlaValLeuValAspLeuGluProGlyThrMetAspSerValArgSerGlyProPheGlyGlnLeuPheArgProAspAsnTyrValPheGlyGlnSerGly

701 GCTGTCCTTGTTGACTTGGAGCCAGGAACCATGGATTCTGTCCGTTCTGGACCATTCGGACAACTTTTCCGTCCAGACAATTACGTATTTGGTCAAAGCG

801

AlaGlyAsnAsnTrpAlaLysG1yHisTyrThrGluGLyAlaGluLeuVa1AspAsnValLeuAspValValArgLysGluAlaGluSerThrAspCys GTGCTGGAAACAATTGGGCCAAAGGACACTACACCGAGGGAGCAGAACTTGTAGACAATGTTCTTGACGTTGTCAGAAAAGAAGCAGAAAGCACAGATTG

LeuGlnGlyPheGlnLeuThrHisSerLeuGlyGlyG1yThrGlySerGlyMetGlyThrLeuLeuIleSerLysIleArgGluGluTyrProAspArg CCTTCAAGGATTTCAACTTACTCACTCACTTGGAGGAGGTACTGGATCTGGAATGGGAACCCTTCTCATTTCAAAAATTCGCGAGGAATATCCTGACCGG

IleMetAsnThrPheSerValValProSerProLysVa1SerAspThrValValGluProTyrAsnAlaThrLeuSerValHisGinLeuValG1uAsnThr 1001 ATAATGAACACCTTCTCGGTAGTTCCAAGTCCAAAAGTATCCGACACTGTAGTCGAACCCTACAATGCCACCCTCTCTGTCCACCAGCTTGTCGAGAACA

AspSerThrPheCysI LeAspAsnGluAlaLeuTyrAspIleCys PheArgThrLeuLysLeuThrThrProThrTyrGlyAspLeuAsnHisLeuVal 1101 CCGACTCGACGTTCTGCATTGATAATGAGGCCTTGTATGACATCTGTTTCCGCACTCTGAAACTGACGACACCGACATATGGAGACCTTAACCATCTGGT

SerAlaThrMetSerGlyValThrThrCysLeuArgPheProGIyGInLeuAsnAlaAspLeuArgLysLeuAlaValAsnMetValProPheProArg 1201 CAGTGCCACAATGAGCGGCGTCACTACTTGCCTCCGCTTCCCTGGTCAACTCAATGCGGATCTACGAAAGTTGGCAGTGAACATGGTTCCATTCCCACGT

LeuHis PhePheMetProGlyPheAlaProLeuThrSerArgSerAsnGlnGln

1301 CTTCACTTCTTCATGCCAGGATTCGCACCACTGACTAGCAGAAGCAATCAGCAGGTTTGAATAATGAAAAAAAAACAACTTTGTGATAACTTAGTTTTTA

TyrArgAlaIleThrValProGluLeuThrGlnGlnCys PheAspAlaLysAsnMetMetAlaAlaCysAspProArgHisGlyArg TyrLeuThrAla 1401 GTATCGTGCCATTACTGTCCCTGAGCTGACCCAACAATGTTTCGACGCAAAGAACATGATGGCTGCATGCGATCCAAGACATGGACGTTATCTCACCGCT

AlaAlaIlePheArgGlyArgMetSerMetLysGluValAspGluGlnMetLeuAsnIleGlnAsnLysAsnSerSerTyrPheValAspTrpIleProAsn 1501 GCTGCCATTTTCCGAGGAAGAATGAGCATGAAGGAGGTTGACGAGCAGATGCTCAACATCCAGAACAAGAACTCTTCCTACTTCGTGGACTGGATTCCAA

AsnVallysThrAlaValCysAspIleProProArgGlyLeuLysMetSerAlaThrPheIleGlyAsnSerThrAlaIleGlnGluLeuPheLysArg 1601 ACAATGTCAAGACCGCAGTTTGTGACATTCCACCAAGAGGATTAAAGATGTCCGCAACATTCATCGGAAACTCCACCGCCATTCAAGAGCTCTTTAAGAG

IleSerGluGlnPheThr

AlaMetPheArgArgLysAlaPheLeuHisTrpTyr

1701 AATCICAGAGCAGTTCACAGGTAAAATTTTACGATTTGTATTTTGACTAATTTCATATTTTTTCCAGCTATGTTCCGCCGCAAAGCTTTCCTTCATTGGT

ThrGlyGluGlyMetAspGluMetGluPheThrGluAlaGluSerAsnMetAsnAspLeuValSerGluTyrGlnGlnTyrGlnGluAlaAlaAlaAsp 1801 ACACTGGCGAGGGAATGGACGAGATGGAATTCACTGAGGCGGAGAGCAACATGAACGATCTTGTTTCGGAATACCAACAATACCAGGAGGCAGCTGCTGA

GluAspAlaAlaGluAlaPheAspglyGluOC

1901 TGAAGATGCCGCCGAAGCGTTCGACGGAGAGTAAATCATATTTCCTAACCAAGTTTTATTGATCGATTGTTATATCATTTTATTCAGCCTTTTTGCTTTG

2001 CTTTTTTTTTCATGGGGATTTCACAATTGATAAATTTTGATTAGCTAAACAACTGTTAAACACGGAATTTAAGGCTTGTTTTTTTTTTAATCAAAAAGCT

Figure 4. Nucleic acid and predicted amino acid sequence of mec-7. Predicted translational start and stop sites are at positions 339 and 1932, respectively. Predicted splice acceptor and splice donor sequences are underlined. One anomaly in the sequence is the predicted $\mathrm{XbaI}$ site at position 629 , which was not detected by restriction mapping analysis.

(Fig. 5). Three of these substitutions represent significant alterations in hydrophobicity (residues 35, 278, and 293), and another results in a charge difference (residue 198). Two of these changes are in amino acids that have hitherto been invariant [Cys (127) and Glu (343)].

\section{Discussion}

Nature of mec-7 activity

mec-7 is likely to encode a $\beta$-tubulin that is selectively required in the $C$. elegans touch cells; mutations in mec-7 do not detectably affect other cells. Various data suggest that loss-of-function mutations are recessive and result in the complete loss of touch sensitivity: (1) Two deletions of the mec-7 locus produce the strong recessive phenotype; (2) the mec-7 locus is not haploinsufficient; (3) e1506/uDf1 animals have no stronger phenotype than $e 1506$ homozygotes; and (4) a screen for alleles that fail to complement mec-7(e1506) identified only mutations resulting in touch insensitivity. Similarly, null mutations in $\beta$-tubulin genes from Saccharomyces cerevisiae (Neff et al. 1983) and Drosophila melanogaster (Kemphues et al. 1983) are expressed recessively. 


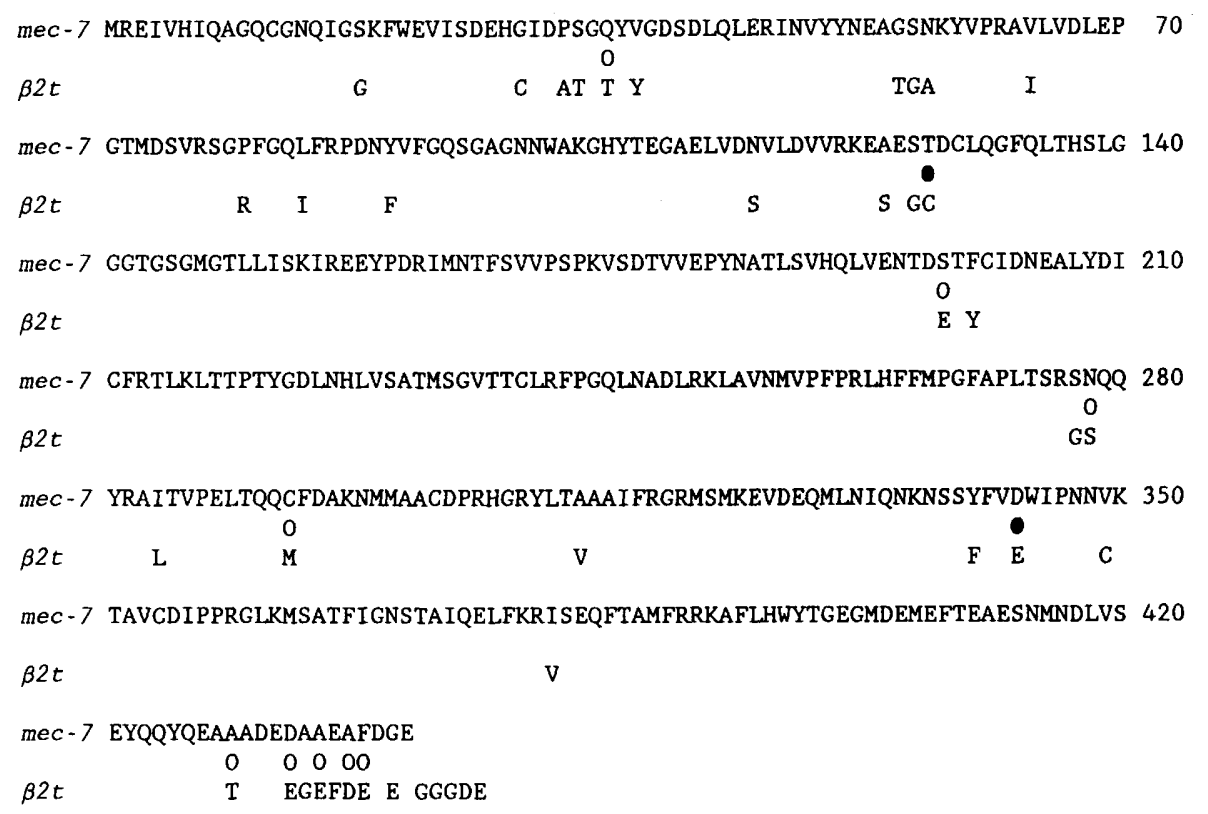

Figure 5. Comparison of amino acid sequences from mec-7 and Drosophila $\beta 2$-tubulin. The entire predicted amino acid sequence of the mec-7 $\beta$-tubulin is shown, but only those differences in the Drosophila sequence $(\beta 2 t)$ are indicated. (O) Novel amino acid substitution; $(\bullet)$ substitution in a previously invariant amino acid.

Dominant and semidominant mec-7 alleles act as antimorphs. Fifteen protofilament microtubules are not found in the touch-insensitive heterozygotes of dominant alleles (Chalfie and Thomson 1982). Abnormal gene products in these animals are likely to interfere with wild-type proteins to prevent the formation and/or stability of these microtubules. The sequences of $\alpha$ - and $\beta$-tubulins are highly conserved among eukaryotes, and the homologies extend throughout the proteins (Cleveland and Sullivan 1985). This degree of conservation suggests that tubulins cannot tolerate structural change without loss or change of function. Thus, one would expect a large proportion of tubulin mutations to encode aberrant products that fail to interact normally with other microtubule proteins. These mutations are likely to be expressed dominantly, as we have found for the mec-7 $\beta$-tubulin gene. Consistent with this hypothesis, dominant alleles constitute a considerable proportion of the $\beta$-tubulin mutations in Schizosaccharomyces pombe (9 of 9; Yamamoto 1980), S. cerevisiae (15 of 65; Thomas et al. 1985), and D. melanogaster ( 2 of 5; Kemphues et al. 1979, 1983).

\section{Position dependence of touch sensitivity}

The hypomorphic mutants show a position dependence of touch sensitivity in the head and in the tail. The degree of touch sensitivity does not correlate with the dis-

Table 2. Effects of increased gene dosage on the expression of dominant mec-7 phenotypes

\begin{tabular}{lcccr}
\hline Genotype & $\begin{array}{l}\text { Number } \\
\text { of animals }\end{array}$ & $\begin{array}{l}\text { Percent touch } \\
\text { insensitive }\end{array}$ & $\begin{array}{l}\text { Percent partially } \\
\text { touch sensitive }\end{array}$ & $\begin{array}{l}\text { Percent touch } \\
\text { sensitive }\end{array}$ \\
\hline e1527/+ & 49 & 94 & 6 & 0 \\
$e 1527 /+/+$ & 45 & 0 & 0 & 100 \\
$n 434 /+$ & 37 & 97 & 3 & 0 \\
$n 434 /+/+$ & 32 & 3 & 97 & 0 \\
$u 18 /+$ & 15 & 67 & 33 & 0 \\
$u 18 /+/+$ & 16 & 0 & 75 & 25 \\
$u 129 /+$ & 9 & 44 & 56 & 0 \\
$u 129 /+1+$ & 40 & 5 & 60 & 35 \\
$u 162 /+$ & 28 & 50 & 50 & 0 \\
$u 162 /+/+$ & 41 & 0 & 71 & 29 \\
$n 434 /+\left(15^{\circ}\right)$ & 10 & 100 & 0 & 0 \\
$n 434 /+/+\left(15^{\circ}\right)$ & 13 & 0 & 62 & 38 \\
\hline
\end{tabular}


tance from the cell bodies of the touch cells but with the distance from the touch cell synapses. Because these mutants can respond to touch at some positions, the touch cells appear to make proper connections. Other observations, using Nomarski optics and immunofluorescence microscopy, confirm that the touch cell processes appear normal (C. Savage and M. Chalfie, unpubl.) We do not yet know whether touch cells in these mutants contain 15-protofilament microtubules. The partial touch sensitivity suggests that the mec-7 $\beta$-tubulin plays a role in sensory transduction. The 15 -protofilament microtubules may function, actively or passively, in the generation of signals /Chalfie and Thomson 1982). Motor neurons in the large nematode Ascaris do not produce action potentials, only graded potentials (Stretton et al. 1985). If the touch cells in C. elegans act similarly, the magnitude of the signal may be so reduced in hypomorphic mec-7 mutants that it cannot reach the synapses unless generated very near to them; or these mutants may contain less stable microtubules that can be stabilized by proteins found preferentially near the synapses. Alternatively, the microtubules may be necessary for structural integrity; in the absence of these microtubules, a signal cannot propagate along the touch cell process. We believe that this last possibility is unlikely, however, because other neurons in the nematode can propagate signals without 15 -protofilament microtubules.

\section{Tubulin protein structure and function}

When polymerized in vitro, tubulins vary greatly in protofilament number unless grown from axonemal seeds (Scheele et al. 1982) or centrosomes (Evans et al. 1985). These experiments have led to the conclusion that nucleation of microtubules is a determinant of protofilament number. Our finding that mec-7 is a $\beta$-tubulin gene suggests that the constituent tubulins of the microtubule may also affect the number of protofilaments. Still, the mec-7 product could reside at the nucleation sites of touch cell microtubules or could affect protofilament number via specific binding to a microtubule-associated protein. Moreover, mec-7 is not sufficient for the formation of 15-protofilament microtubules because mutations in three other genes also result in the loss of these microtubules (Chalfie and Au 1988); nor do we know whether mec-7 is expressed in other cell types that do not contain 15-protofilament microtubules.

The mec-7 $\beta$-tubulin may be required for the formation of 15-protofilament microtubules because of structural features inherent in the protein. Alternatively, the mec-7 gene may be necessary because it maintains a particular level of tubulin expression. Either of these possibilities represents an unusual method of influencing microtubule structure. We believe, however, that the second possibility, control of $\beta$-tubulin levels, is unlikely because (1) sufficient tubulin (from other genes) is produced in mec-7 null mutants to form $\sim 10011$-protofilament microtubules (Chalfie and Thomson 1982); (2) altering wild-type gene dosage has no effect on touch
Table 3. Percentage identity between the amino acid sequence of mec-7 and that of other $\beta$-tubulins

\begin{tabular}{|c|c|c|}
\hline$\beta$-Tubulin & $\begin{array}{l}\text { Percent } \\
\text { identity }\end{array}$ & Reference \\
\hline Physarum $\beta 1$ & 86 (398 aa) & $\begin{array}{l}\text { Singhofer-Wowra et al. } \\
\text { (1986) }\end{array}$ \\
\hline Physarum $\beta 2$ & 79 & Burland et al. (1988) \\
\hline $\begin{array}{l}\text { Chlamydomonas } \\
\text { reinhardtii }\end{array}$ & 85 & Youngbloom et al. (1984) \\
\hline Trypanosome & 81 & Kimmel et al. (1985) \\
\hline Neurospora crassa & 82 & Orbach et al. (1986) \\
\hline Aspergillus $\beta 1 / 2$ & 81 & May et al. (1987) \\
\hline Aspergillus $\beta 3$ & 76 & May et al. (1987) \\
\hline S. pombe & 75 & Hiraoka et al. (1984) \\
\hline S. cerevisiae & 74 & Neff et al. (1983) \\
\hline Drosophila $\beta 2$ & 92 & Rudolph et al. (1987) \\
\hline Drosophila $\beta 3$ & 88 & Rudolph et al. (1987) \\
\hline Chicken $\beta 1$ & 92 & Sullivan et al. $(1985)$ \\
\hline Chicken $\beta 2$ & 92 & Sullivan et al. (1985) \\
\hline Chicken $\beta 3$ & 92 & $\begin{array}{l}\text { Sullivan and Cleveland } \\
\qquad(1986)\end{array}$ \\
\hline Chicken $\beta 4$ & 90 & $\begin{array}{l}\text { Sullivan and Cleveland } \\
\text { (1984) }\end{array}$ \\
\hline Chicken $\beta 5$ & 90 & $\begin{array}{l}\text { Sullivan and Cleveland } \\
\text { (1986) }\end{array}$ \\
\hline Human M40 & 91 & Lewis et al. (1985) \\
\hline Human $\beta 2$ & 93 & Lewis et al. (1985) \\
\hline Human $\beta 4$ & $90(379 \mathrm{aa})$ & $\begin{array}{l}\text { Sullivan and Cleveland } \\
\qquad 1986)\end{array}$ \\
\hline Human $\beta 5$ & 91 & Lewis et al. (1985) \\
\hline Pig $\beta 1$ & 92 & Krauhs et al. (1981) \\
\hline Mouse $\beta 2$ & $91(204$ aa) & $\begin{array}{l}\text { Sullivan and Cleveland } \\
(1986) ; \text { Lewis et al. } \\
(1985)\end{array}$ \\
\hline Mouse $\beta 4$ & $92(375 \mathrm{aa})$ & Lewis et al. (1985) \\
\hline Mouse $\beta 4^{\prime}$ & 93 (371 aa) & $\begin{array}{l}\text { Sullivan and Cleveland } \\
\qquad(1986)\end{array}$ \\
\hline Mouse $\beta 5$ & 91 & $\begin{array}{l}\text { Sullivan and Cleveland } \\
\{1986\}\end{array}$ \\
\hline
\end{tabular}

$\beta$-Tubulin amino acid sequences were compared to $\mathrm{mec}-7$ along its 441-amino-acid length, except where partial sequences were available, as indicated by the amino acid numbers in parentheses $|a|$.

sensitivity; and (3) Scheele et al. (1982) found no significant effect of tubulin concentration of protofilament number of microtubules polymerized in vitro. Moreover, experiments by Aamodt and Culotti (1986) support a role for microtubule proteins in the determination of protofilament numbers: Tubulins and microtubule-associated proteins isolated from C. elegans predominantly formed microtubules with 9-11 protofilaments in vitro, whereas those from bovine brain predominantly formed microtubules with 13 protofilaments.

The mec-7 tubulin is very similar to other $\beta$-tubulins, so that only a few amino acid changes may be needed to permit the assembly of 15-protofilament microtubules. Figure 5 compares the mec-7 sequence with that of the testis-specific $\beta$-tubulin from Drosophila (Rudolph et al. 1987). This latter $\beta$-tubulin is required for the formation of all cytoplasmic, spindle, and axonemal microtubules 
(none of which have 15-protofilaments) during spermatogenesis, beginning with meiosis (Raff 1984). Of the first 430 residues in the mec-7 peptide, only 7 are not shared by the Drosophila $\beta$-tubulin or by any other known $\beta$-tubulins (Fig. 5). Possibly of most significance to the secondary structure of mec-7, because sulfhydryl groups may play a role in the regulation of tubulin assembly (Nishida and Kobayashi 1977; Burchill et al. 19781, are the substitutions of a threonine for a cysteine at residue 127 and a cysteine for a methionine at residue 293. The cysteine at position 127 has been conserved in every other sequenced $\beta$-tubulin (Sullivan and Cleveland 1986; Rudolph et al. 1987; Burland et al. 1988), including two other C. elegans $\beta$-tubulins (Gremke 1986; M. Driscoll, E. Dean, E. Reilly, E. Bergholz, and M. Chalfie, unpubl.). Residue 293 lies in the 'hinge' region between the amino- and carboxyterminal domains. A single amino acid change at position 288 in the hinge region in the Drosophila $\beta$-tubulin prevents polymerization of the tubulin into functional microtubules without preventing heterodimer or protofilament formation (Rudolph et al. 1987). This region may thus be important for interactions between protofilaments.

\section{Effects of tubulin mutations on microtubule structure and function}

Although the mec-7 $\beta$-tubulin is required specifically in the touch cells in C. elegans, it is not the only $\beta$-tubulin that can be expressed in this cell type. In the touch cell process of mec-7(e1343) and mec-7(e1506) mutants, the 15-protofilament microtubules have been replaced by 11-protofilament microtubules (Chalfie and Thomson 1982). Because process outgrowth in these mutants is inhibited by benomyl (Chalfie and Thomson 1982), the microtubules in these processes are likely to contain a benomyl-sensitive component. Studies of benomyl sensitivity in C. elegans have shown that only one gene product, the $\beta$-tubulin encoded by ben-1, confers benomyl sensitivity to microtubules (Chalfie et al. 1986). Therefore, the mec-7 mutant touch cells are likely to be expressing the $\beta$-tubulin gene ben-1. We have now examined a deletion null mutant $[$ mec-7/u448)] and found that the touch cell processes in these animals also contain small-diameter microtubules like those found in other neurons (data not shown). We do not yet know whether the ben-1 gene or other $\beta$-tubulin genes are expressed in wild-type touch cells. $\beta$-Tubulin expression in these mutants may be similar to that in Aspergillus nidulans, where the benA22 benomyl-resistant $\beta$-tubulin can substitute in conidiation for the $\beta-3$ tubulin in fungi lacking $\beta-3$ activity (Weatherbee et al. 1985). In mec-7 mutants, however, the ben-1 $\beta$-tubulin is not sufficient for the assembly of 15 -protofilament microtubules.

The testis-specific $\beta$-tubulin gene $(\beta 2 t)$ in Drosophila also functions cell specifically (Kemphues et al. 1983). The absence of all microtubule types in the testes of $\beta 2 t$ mutant males contrasts with our findings, where the loss of mec-7 gene activity prevents only the assembly of 15-protofilament microtubules. Although the $\beta 2 t$ tubulin is multifunctional, it may be specifically required for the formation of one or more of the microtubule types in which it is expressed. Consistent with this hypothesis, some partial loss-of-function mutations in $\beta 2 t$ have effects either on the meiotic spindle or on the flagellar axoneme, but not both (Fuller 1986). Similarly, we do not yet know whether the mec-7 tubulin is incorporated into 11-protofilament microtubules in other cell types.

Other tubulin mutations have been identified by resistance or supersensitivity to benzimidazole compounds in A. nidulans (Sheir-Neiss et al. 1978; Morris et al. 1979) Physarum (Burland et al. 1984), S. pombe (Yamamoto 1980), and S. cerevisiae (Thomas et al. 1985). These mutations have been useful in identifying tubulin genes and in determining when and where these genes are expressed. Because such alleles represent a specific class of tubulin mutations, however, they cannot directly elucidate the complete loss-of-function phenotype. Mutations in essential tubulin genes have been identified in the yeasts S. cerevisiae (Hiraoka et al. 1984; Adachi et al. 1986) and S. pombe (Thomas et al. 1985; Schatz et al. 1986) and in Drosophila (Matthews and Kaufman 1987). Because of the lethality of these mutations, the effects of the mutant tubulins on microtubule structure are difficult to determine. Because the mec-7 $\beta$-tubulin is not essential for the worm or for touch cell growth, we have been able to isolate a large, heterogenous set of mutations in the gene. It should be possible to identify protein domains required for incorporation into the 15-protofilament microtubules by mapping and sequencing the mutations in these alleles.

\section{Methods \\ Growth and maintenance of nematode strains}

Animals were grown as described by Brenner (1974). Unless otherwise noted, animals were kept at $25^{\circ} \mathrm{C}$ because they grow most rapidly at this temperature. Most strains derive from the wild-type C. elegans var. Bristol (strain N2). In addition to the mec-7 alleles, we used the following mutations on linkage group X: lon-2(e678), mec-2(e1084), unc-6(e78), dpy-7(e88), unc-18(e81), dpy-6(e14), uDf1, and stDp2(X;II); and the following mutations on linkage group III: lon-1(e185) and sup-5(e1464). Except for $u D f 1, s t D p 2$, and sup-5, all of these mutations were characterized by Brenner (1974). The deficiency $u D f 1$ was isolated as described below. stDp2 is a duplication of the region of the $\mathrm{X}$ chromosome that includes mec-7, which has been translocated to chromosome II ( $R$. Waterston, pers. comm.). Two copies of $s t D p 2$ are lethal. The amber suppressor mutation sup-5(e1464) is described by Waterston and Brenner (1978) and Wills et al. (1983). Except for the mec-7 alleles identified by failure to complement mec-7(e1506), as described below, all mec-7 alleles were isolated in previous screens for touch-insensitive mutants (Chalfie and Sulston 1981; Chalfie and Thomson 1982; Chalfie and Au 1988); 37 were identified following EMS mutagenesis; 7 (u440, u443, u445, u448, u449, $u 451, u 453$ ) were identified following $\gamma$-ray mutagenesis; and 2 (u382 and u388) derived from the mutator strain TR679 [mut-2(r459)] (Collins et al. 1987) that generates spontaneous mutations by increasing the rate of transposition. 


\section{Touch sensitivity}

Touch sensitivity was assessed as described previously /Chalfie and Sulston 1981). Touch-sensitive $(+)$ animals move away when a fine hair is drawn across their bodies. Completely touch-insensitive ( - ) animals respond to $<30 \%$ of the touches. Some animals show a partial $( \pm)$ response in that they respond to between 30 and $70 \%$ of the touches. Finally, some animals show a position dependence of touch sensitivity in that they respond to touch only at certain positions along their lengths.

\section{Mutagenesis}

We screened for noncomplementing mec-7 alleles by mating lon-2 mec-7(e1506) males to dpy-6 hermaphrodites that had been mutagenized with EMS (Brenner 1974) and examining their progeny for touch sensitivity. Touch-insensitive progeny were isolated and allowed to segregate animals homozygous for new mec-7 alleles linked to $d p y-6$. These mutations have allele numbers $u 427-u 434$.

To screen for deficiencies, we irradiated wild-type males for $4.25 \mathrm{~min}$ (total radiation $=3000$ rads) with a ${ }^{137} \mathrm{Cs}$ gammator, mated them to mec-7(e1506) dpy-6 hermaphrodites, and screened for touch-insensitive cross progeny. Of $2700 \mathrm{~F}_{1}$ progeny, one such mutation, $u D f 1$, was identified. This deficiency is lethal as a homozygote; $u D f 1 / m e c-7 d p y-6$ heterozygotes segregate only heterozygotes and mec-7 dpy-6 homozygotes. $u D f 1$ fails to complement xol-1 (L. Miller, pers. comm.), unc-6, dpy-7, unc-18, and mec-7; complements lon-2 and $d p y-6$; and is completely covered by stDp2. Because unc- 18 and xol-1 flank mec-7 on opposite sides on the genetic map, it is likely that the deficiency $u D f 1$ completely deletes the mec-7 gene.

\section{Identification of revertants of TR679-derived mutations}

To revert the TR679-derived alleles $u 382$ and $u 388$, we first reintroduced the mut-2(r459) mutation (Collins et al. 1987) from the strain $\mathrm{HH}^{\star} 10$ (a gift from M. Finney, Massachusetts General Hospital, Boston). Individual mut-2; mec-7(u382) and mut-2;mec-7(u388) animals were plated at $20^{\circ} \mathrm{C}$, and 8800 and $1700 F_{1}$ progeny, respectively, were tested for touch sensitivity. Two wild-type revertants (u382u473 and u388u474) were identified and separated from mut-2 by repeated crosses with mec-7(e1506).

\section{Genetic mapping}

The position of mec-7 on the genetic map (Fig. 1) was refined by the following three-factor cross using standard procedures (Brenner 1974); 2 of 35 Unc and 36 of 38 Dpy recombinants from unc-18 $+d p y-6 /+m e c-7+$ animals segregated mec-7 progeny. These data place mec-7 $\sim 0.02$ map units to the right of unc- 18 on the $\mathrm{X}$ chromosome.

\section{Suppression tests}

To identify nonsense alleles, we looked for effects of the amber suppressor mutation sup-5(e1464) on mec-7 expression. For each allele of mec-7, a hermaphrodite of genotype lon-1 sup-5/ $++; m e c-7 /+$ was constructed at $20^{\circ} \mathrm{C}$ and its Lon progeny were examined for touch sensitivity. None of the mutations were detectably suppressed. Because many of the mec-7 alleles produce a semidominant or dominant phenotype, the insertion of a novel amino acid into the protein by a suppressor tRNA might enhance, rather than suppress, an amber mutation (Winston and Botstein 1981). The phenotypes of the recessive alleles were not, however, detectably enhanced in the sup -5 background.

\section{Construction of mec-7(d) $/+/+$ strains}

We increased wild-type mec-7 dosage in animals with dominant mec-7 mutations [designated as mec-7(d)] by constructing strains containing $s t D p 2$. stDp2/ + ;uDf1 males were mated to dpy-7 mec-7(d) hermaphrodites. Their non-Dpy male cross progeny $(s t D p 2 /+; d p y-7$ mec-7) were mated to $d p y-7$ unc-18 hermaphrodites. Non-Dpy hermaphrodites from this mating [genotype $s t D p 2 / \times ; d p y-7$ unc- $18+/ d p y-7+m e c-7(d)]$ have two copies of the wild-type gene and one copy of a dominant allele of $m e c-7$. These animals are designated as $m e c-7(d) /+1+$.

\section{Construction of $\mathrm{uDf} 1 /+$ animals}

We determined the effect on touch sensitivity of decreased wild-type mec-7 dosage by mating wild-type males to uDf1/ mec-7(e1506)dpy-6(e14) hermaphrodites. Non-Dpy hermaphrodites, which are either $u D f 1 /+$, mec- $7 d p y-6 /+$, or $u D f 1 /$ mec-7 $d p y-6$, were picked and scored for touch sensitivity. Those animals that segregated dead eggs and no Dpy progeny were designated $u D f 1 /+$.

\section{Electron microscopy}

Animals were fixed in glutaraldehyde, acrolein, and $\mathrm{OsO}_{4}$ and processed for electron microscopy as before /Chalfie and Thomson 1979|, except that the animals were stained en bloc in $0.5 \%$ uranyl acetate and embedded in epon.

\section{Recombinant DNA techniques.}

DNA was extracted from C. elegans, as described by Emmons et al. (1979). Genomic DNA was digested with EcoRI from New England Biolabs in accordance with their instructions, except that $5 \mathrm{~mm}$ spermidine was added to all reactions. Southern blots of genomic DNA were probed with the $\lambda$ clone NW \#BT4, the cosmid R02A8, or a BgIII subfragment of $\sim 10 \mathrm{~kb}$ isolated from R02A8. The R02A8 cosmid was identified as containing the tub-2 $\beta$-tubulin gene (Gremke 1986) by comparing its 'fingerprint' (Coulson et al. 1986) to that of the $\lambda$ clone NW \#BT4 that contains this $\beta$-tubulin. The BglII fragment contains all of the DNA sequences of R02A8 that hybridize to a chicken $\beta$-tubulin cDNA clone (Cleveland et al. 1980), a gift of N. Cowan (New York University Medical Center). Probes were labeled with ${ }^{32} \mathrm{P}$ using an oligolabeling kit from Pharmacia or by nick translation. Other techniques were performed according to Maniatis et al. (1982).

The R02A8 cosmid is part of a contiguous set of cosmids (contig) that also contains the vit-1 gene (Heine and Blumenthal 1986). An adjacent cosmid in this set, C27C10, was used to localize the contig to the central portion of the $\mathrm{X}$ chromosome, the same region as mec-7, by in situ hybridization as described previously (Albertson 1985).

DNA sequencing was performed according to the method of Sanger et al. (1977). A 5.0-kb XbaI fragment was subcloned from the tub-2 clone (Gremke 1986) as two XbaI-HindIII fragments into Stratagene's pKS vector. Subclones in both orientations were treated according to the method of Heinkoff (1984) to create a series of deletions. Single-stranded DNA from superinfected cultures was then subjected to sequence analysis. The sequence shown in Figure 4 was confirmed on both strands. 


\section{Acknowledgments}

We are grateful to Dr. Eric Holtzman and Wanda Setlik for help with electron microscopy. We are grateful for Audrey Chin's excellent help with the sequence analysis. This work was supported by U.S. Public Health Service grants GM-30997 and AI-19399 to M.C., a N.S.E.R.C. grant to J.G.C., Mt. Sinai Hospital Research Fellowship to M.H., and a National Science Foundation Graduate Fellowship to C.S. D.G.A. is a Dupont Fellow.

\section{References}

Aamodt, E.J. and J.G. Culotti. 1986. Microtubules and microtubule-associated proteins from the nematode Caenorhabditis elegans: Periodic cross-links connect microtubules in vitro. I. Cell Biol. 103: 23-31.

Adachi, Y., T. Toda, O. Niwa, and M. Yanagida. 1986. Differential expressions of essential and nonessential $\alpha$-tubulin genes in Schizosaccharomyces pombe. Mol. Cell. Biol. 6: 2168-2178.

Albertson, D.G. 1985. Mapping muscle protein genes by in situ hybridization using biotin-labeled probes. EMBO I. 4: 24932498.

Brenner, S. 1974. The Genetics of Caenorhabditis elegans. Genetics 77: 71-94.

Burchill, B.R., J.M. Oliver, C. B. Pearson, E.D. Leinbach, and R. D. Berlin. 1978. Microtubule dynamics and glutathione metabolism in phagocytizing human polymorphonuclear leukocytes. I. Cell Biol. 76: 439-447.

Burland, T.G., E.C.A. Paul, M. Oetliker, and W.F. Dove. 1988. A gene encoding the major $\beta$-tubulin of the mitotic spindle in Physarum polycephalum plasmodia. Mol. Cell Biol. 8: $1275-1281$.

Burland, T.G., T. Schedl, K. Gull, and W.F. Dove. 1984. Genetic analysis of resistance to benzimidazoles in Physarum: Differential expression of $\beta$-tubulin genes. Genetics 108: 123141.

Burton, P.R., R.E. Hinkley, and G.B. Pierson. 1975. Tannic acid-stained microtubules with 12,13 , and 15 protofilaments. J. Cell Biol. 65: 227-233.

Chalfie, M. and M. Au. 1988. Genetic control of differentiation of the C. elegans touch receptor neurons. Science 243: 1027-1033.

Chalfie, M. and J. Sulston. 1981. Developmental genetics of the mechanosensory neurons of Caenorhabditis elegans. Dev. Biol. 82: 358-370.

Chalfie, M. and J.N. Thomson. 1982. Structural and functional diversity in the neuronal microtubules of Caenorhabditis elegans. J. Cell Biol. 93: 15-23.

Chalfie, M., E. Dean, E. Reilly, K. Buck, and J.N. Thomson. 1986. Mutations affecting microtubule structure in Caenorhabditis elegans. J. Cell Sci. Suppl. 5: 257-271.

Chalfie, M., J.E. Sulston, J.G. White, E. Southgate, J.N. Thomson, and S. Brenner. 1985. The neural circuit for touch sensitivity in Caenorhabditis elegans. I. Neurosci. 5: 956964.

Cleveland, D.W. 1987. The multi-tubulin hypothesis revisited: What have we learned? J. Cell Biol. 104: 381-383.

Cleveland, D.W. and K. F. Sullivan. 1985. Molecular biology and genetics of tubulin. Annu. Rev. Biochem. 54: 331-365.

Cleveland, D.W., M.A. Lopata, R.J. Macdonald, N.J. Cowan, W.J. Rutter, and M.W. Kirschner. 1980. Number and evolutionary conservation of $\alpha$ - and $\beta$-tubulin and cytoplasmic $\beta$ and $\lambda$-actin genes using specific cloned cDNA probes. Cell 20: $95-105$.
Collins, J., B. Saari, and P. Anderson. 1987. Activation of a transposable element in the germ line but not the soma of Caenorhabditis elegans. Nature 328: 726-728.

Coulson, A., J. Sulston, S. Brenner, and J. Karn. 1986. Toward a physical map of the genome of the nematode Caenorhabditis elegans. Proc. Natl. Acad. Sci. 83: 7821-7825.

Dustin, P. 1984. Microtubules, 2nd ed. Springer-Verlag, Berlin, New York.

Edgley, M.L. and D.L. Riddle. 1987. The nematode Caenorhabditis elegans. Genet. Maps 4: 351-365.

Eichenlaub-Ritter, U. and J.B. Tucker. 1984. Microtubules with more than 13 protofilaments in the dividing nuclei of ciliates. Nature 307: 60-62.

Emmons, S.C. 1988. The genome. In The nematode Caenorhabditis elegans (ed. W.B. Wood), pp. 47-79. Cold Spring Harbor Laboratory, Cold Spring Harbor, New York.

Emmons, S.C., M.R. Klass, and D. Hirsch. 1979. Analysis of the constancy of DNA sequences during development and evolution of the nematode Caenorhabditis elegans. Proc. Nat. Acad. Sci. 76: 1333-1337.

Evans, L., T. Mitchison, and M. Kirschner. 1985. Influence of the centrosome on the structure of nucleated microtubules. I. Cell Biol. 100: 1185-1191.

Fuller, M.T., 1986. Genetic analysis of spermatogenesis in Drosophila: The role of the testis-specific $\beta$-tubulin and interacting genes in morphogenesis. In Gametogenesis and the early embryo (ed. J. Gall), pp. 19-41. Forty-fourth Symposium of the Society for Developmental Biology, Alan R. Liss, New York.

Fulton, C. and P.A. Simpson. 1976. Selective synthesis and utilization of flagellar tubulin. The multitubulin hypothesis. In Cell motility (ed. R. Goldman, T. Pollard, and J. Rosenbaum|. pp. 987-1005. Cold Spring Harbor Laboratory, Cold Spring Harbor, New York.

Gremke, L. 1986. "Cloning and molecular characterization of the tubulin genes of Caenorhabditis elegans: Nucleotide sequence analysis of a tubulin gene." Ph.D. thesis, Northwestern University, Evanston, Illinois.

Heine, U. and T. Blumenthal. 1986. Characterization of regions of the Caenorhabditis elegans X chromosome containing vitellogenin genes. J. Mol. Biol. 188: 301-312.

Henikoff, S. 1984. Unidirectional digestion with exonuclease III creates targeted breakpoints for DNA sequencing. Gene 28: 351-359.

Hiraoka, T., T. Toda, and M. Yanagida. 1984. The NDA3 gene of fission yeast encodes $\beta$-tubulin: A cold sensitive nda3 mutation reversibly blocks spindle formation and chromosome movement in mitosis. Cell 39: 349-358.

Kemphues, K.J., E.C. Raff, and T.C. Kaufman. 1983. Genetic analysis of $\beta 2 t$, the structural gene for a testis-specific $\beta$-tubulin subunit in Drosophila melanogaster. Genetics 105: 345-356.

Kemphues, K.J., R.A. Raff, T.C. Kaufman, and E.C. Raff. 1979. Mutation in a structural gene for a $\beta$-tubulin specific to testis in Drosophila melanogaster. Proc. Natl. Acad. Sci. 76: 3991-3995.

Kimmel, B.E., S. Samson, J. Wu, R. Hirschberg, and L.R. Yarbrough. 1985. Tubulin genes of the African trypanosome Trypanosoma brucei rhodesiense: Nucleotide sequence of a $3.7 \mathrm{~kb}$ fragment containing genes for alpha and beta tubulins. Gene 35: 237-248.

Krauhs, E., M. Little, T. Kempfl, R. Hofer-Warbinek, W. Ade, and $H$. Ponstingl. 1981. Complete amino acid sequence of $\beta$-tubulin from porcine brain. Proc. Natl. Acad. Sci. 78: 4156-4160.

Lewis, S.A., M.E. Gilmartin, J.L. Hall, and N.J. Cowan. 1985. 
Three expressed sequences within the human $\beta$-tubulin multigene family each define a distinct isotype. J. Mol. Biol. 182: $11-20$.

L'Hernault, S.W. and J.L. Rosenbaum. 1985. Reversal of the posttranslational modification on Chlamydomonas flagellar $\alpha$-tubulin occurs during flagellar resorption. I. Cell Biol. 100: 457-462.

Maniatis, T., E.F. Fritsch, and J. Sambrook. 1982. Molecular cloning: A laboratory manual. Cold Spring Harbor Laboratory, Cold Spring Harbor, New York.

Matthews, K.A. and T.C. Kaufman. 1987. Developmental consequences of mutations in the $84 \mathrm{~B} \alpha$-tubulin gene of Drosophila melanogaster. Dev. Biol. 119: 100-112.

May, G.S., M.L.-S. Tsang, H. Smith, S. Fidel, and N.R. Morris. 1987. Aspergillus beta-tubulin genes are unusually divergent. Gene 55: 231-243.

Mogensen, M.M. and J.B. Tucker. 1987. Evidence for microtubule nucleation at plasma membrane-associated sites in Drosophila. J. Cell Sci. 88: 95-107.

Morris, N.R., M.H. Lai, and C.E. Oakley. 1979. Identification of a gene for $\alpha$-tubulin in Aspergillus nidulans. Cell 16: 437 442.

Nagano, T. and F. Suzuki. 1975. Microtubules with 15 subunits in cockroach epidermal cells. J. Cell Biol. 64: 242-245.

Neff, N.F., J.H. Thomas, P. Grisafi, and D. Botstein. 1983. Isolation of the $\beta$-tubulin gene from yeast and demonstration of its essential function in vivo. Cell 33: 211-219.

Nishida, E. and T. Kobayashi. 1977. Relationship between tubulin SH groups and bound guanine nucleotides. J. Biochem. (Tokyo) 81: 343-347.

Orbach, M.J., E.B. Porro, and C. Yanofsky. 1986. Cloning and characterization of the gene for the $\beta$-tubulin from a benomyl-resistant mutant of Neurospora crassa and its use as a dominant selectable marker. Mol. Cell Biol. 6: 2452-2461.

Raff, E.C. 1984. Genetics of microtubule systems. J. Cell Biol. 99: $1-10$.

Rudolph, J.E., M. Kimble, H.D. Hoyle, M.A. Subler, and E.C. Raff. 1987. Three Drosophila $\beta$-tubulin sequences: A developmentally regulated isoform $(\beta 3)$, the testis-specific isoform ( $\beta 2)$, and an assembly-defective mutation of the testisspecific isoform $\left(\beta 2 t^{8}\right)$ reveal both an ancient divergence in metazoan isotypes and structural constraints for $\beta$-tubulin function. Mol. Cell Biol. 7: 2231-2242.

Saito, K. and K. Hama. 1982. Structural diversity of microtubules in the supporting cells of the sensory epithelium of guinea pig organ of Corti. J. Electron Microsc. 31: 278-281.

Sanger, F., S. Nicklen, and A. R. Coulson. 1977. DNA sequencing with chain-terminating inhibitors. Proc. Natl. Acad. Sci. 74: 5463-5467.

Schatz, P.J., F. Solomon, and D. Botstein. 1986. Genetically essential and nonessential $\alpha$-tubulin genes specify functionally interchangeable proteins. Mol. Cell Biol. 6: 3722-3733.

Scheele, R.B., L.G. Bergen, and G. B. Borisy. 1982. Control of the structural fidelity of microtubules by initiation sites. $I$. Mol. Biol. 154: 485-500.

Sheir-Neiss, G., M.H. Lai, and N.R. Morris. 1978. Identification of a gene for $\beta$-tubulin in Aspergillus nidulans. Cell 15: $639-647$.

Singhofer-Wowra, M., L. Clayton, P. Dawson, K. Gull, and M. Little. 1986. Amino-acid sequence data of $\beta$-tubulin from Physarum polycephalum myxamoebae. Eur. I. Biochem. 161: 669-679.

Stretton, A.O.W., R.E. Davis, J.D. Angstadt, J. E. Donmoyer, and C.D. Johnson. 1985. Neural control of behavior in Ascaris. Trends Neuro. Sci. 8: 294-300.

Sullivan, K.F. and D.W. Cleveland. 1984. Sequence of a highly divergent tubulin reveals regional heterogeneity in the $\beta$-tubulin polypeptide. J. Cell Biol. 99: 1754-1760.

. 1986. Identification of conserved isotype-defining variable region sequences for four vertebrate $\beta$-tubulin polypeptide classes. Proc. Nat. Acad. Sci. 83: 4327-4331.

Sullivan, K.F., J.T.Y. Lau, and D.W. Cleveland. 1985. Apparent gene conversion between $\beta$-tubulin genes yield multiple regulatory pathways for a single $\beta$-tubulin polypeptide isotype. Mol. Cell Biol. 5: 2454-2465.

Thomas, J.H., N.F. Neff, and D. Botstein. 1985. Isolation and characterization of mutations in the $\beta$-tubulin gene of Saccharomyces cerevisiae. Genetics 112: 715-734.

Tilney, L.G., J. Bryan, D.J. Bush, K. Fujiwara, M.S. Mooseker, D.R. Murphy, and D. H. Snyder. 1973. Microtubules: Evidence for 13 protofilaments. J. Cell Biol. 59: 267-275.

Tucker, J.B. 1979. Spatial organization of microtubules. In Microtubules (ed. K. Roberts and J.S. Hyams), pp. 315-357. Academic Press, London.

Tucker, J.B., S.A. Matthews, K.A.K. Hendry, J.B. Mackie, and D.L.J. Roche. 1985. Spindle microtubule differentiation and deployment during micronuclear mitosis in Paramecium. $J$. Cell Biol. 101: 1966-1976.

Waterston, R.H. and S. Brenner. 1978. A suppressor mutation in the nematode acting on specific alleles of many genes. $\mathrm{Na}$ ture 275: 715-719.

Weatherbee, J.A., G.S. May, J. Gambino, and N.R. Morris. 1985. Involvement of a particular species of beta-tubulin (beta3) in conidial development of Aspergillus nidulans. J. Cell Biol. 101: 705-711.

Wills, N., R.F. Gesteland, J. Karn, L. Barnett, S. Bolten, and R.H. Waterston. 1983. The genes sup- $7 \mathrm{X}$ and sup-5 III of C. elegans suppress amber nonsense mutations via altered transfer RNA. Cell 33: 575-583.

Winston, F. and D. Botstein. 1981. Control of lysogenization by phage P22: 2. Mutations $(\operatorname{cly} A)$ in the $c I$ gene that cause increased lysogenization. J. Mol. Biol. 152: 233-246.

Yamamoto, M. 1980. Genetic analysis of resistant mutants to antimitotic benzimidazole compounds in Schizosaccharomyces pombe. Mol. Gen. Genet. 180: 231-234.

Youngbloom, T., J.A. Schloss, and C.D. Silflow. 1984. The two $\beta$-tubulin genes of Chlamydomonas reinhardtii code for identical proteins. Mol. Cell Biol. 4: 2686-2696.

\section{Note}

The nucleotide sequence data reported will appear in the EMBL, GenBank, and DDBJ nucleotide sequence databases under the accession number X15242 mec-7. 


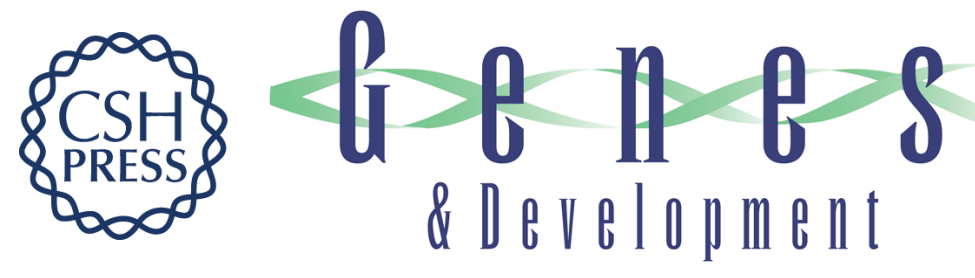

\section{mec-7 is a beta-tubulin gene required for the production of 15-protofilament microtubules in Caenorhabditis elegans.}

C Savage, M Hamelin, J G Culotti, et al.

Genes Dev. 1989, 3:

Access the most recent version at doi:10.1101/gad.3.6.870

References This article cites 60 articles, 30 of which can be accessed free at:

http://genesdev.cshlp.org/content/3/6/870.full.html\#ref-list-1

License

Email Alerting Receive free email alerts when new articles cite this article - sign up in the box at the top Service right corner of the article or click here.

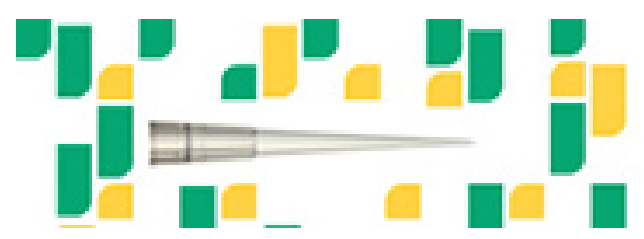

Focused on your science. 